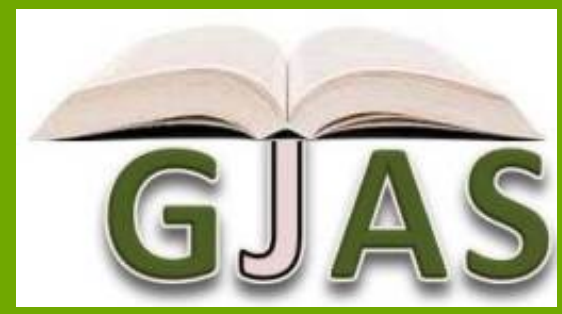

Greeneritouirnal lótagricultural Sciences

ISSN: 2276-7770

ICV: 6.15

Submitted: $15 / 01 / 2016$

Accepted: 25/01/2016

Published: 27/02/201b

DOI: $\underline{\text { http://doi.org/10.15580/GJAS.2016.2.011516011 }}$

Evaluation of exotic and locally adapted

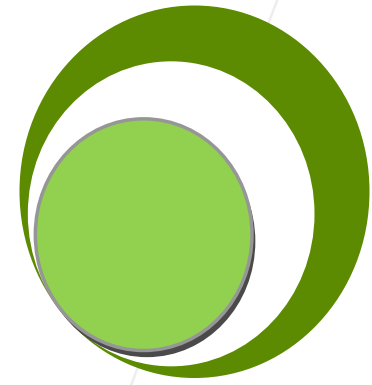

sweetpotato cultivars

to major viruses in

Ethiopia

By

Shiferaw Mekonen

Berhanu Bekele

Tesfaye'Tadesse

Fekadu Gurmu

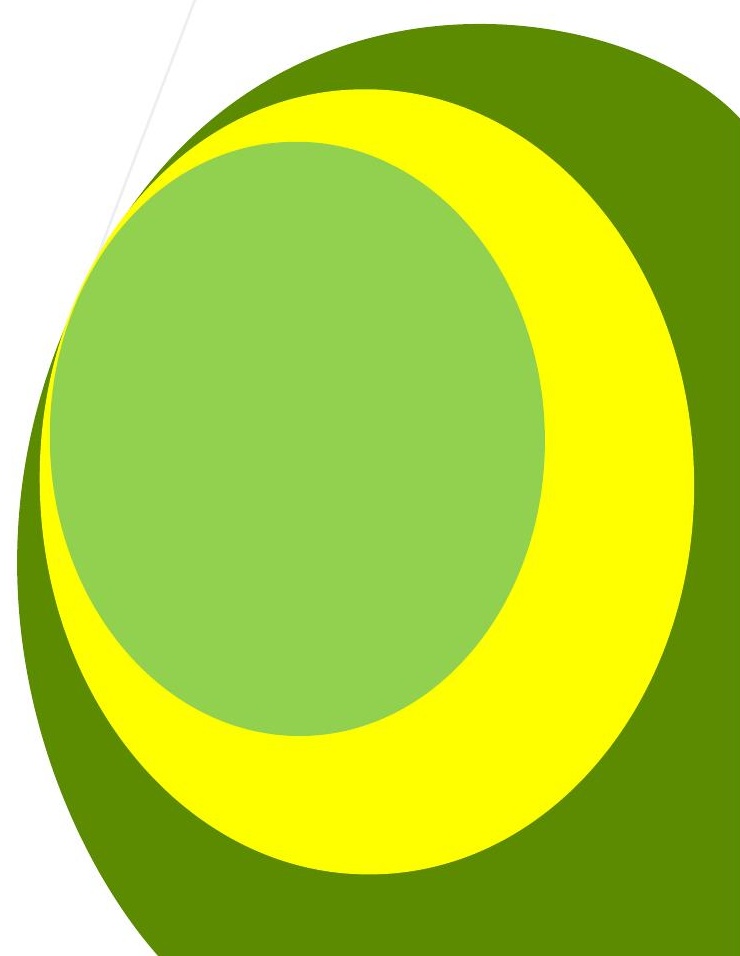




\title{
Evaluation of exotic and locally adapted sweetpotato cultivars to major viruses in Ethiopia
}

\author{
Shiferaw Mekonen ${ }^{1 \star}$, Berhanu Bekele ${ }^{2}$, TesfayeTadesse ${ }^{1}$ and \\ Fekadu Gurmu ${ }^{1}$
}

\author{
${ }^{1}$ Hawassa Agricultural Research Center, P.O. Box 06, Hawassa, Ethiopia \\ ${ }^{2}$ Ambo Plant Protection Research Center, P.O. Box 37, Ambo, Ethiopia \\ *Corresponding Author's E-mail: shifmeko@ gmail. com
}

\begin{abstract}
Sweetpotato virus disease (SPVD) is currently threatening sweetpotato production in Ethiopia than ever, with more viruses unidentified earlier being detected in more recent years. Due to the increased importance of virus diseases, management option using host plant resistance was planned using local cultivars and exotic genotypes for three consecutive years (2011-2013) at Hawassa, Ethiopia. A total of 89 sweetpotato introductions from international sources, and clones of 26 locally adapted cultivars were used for this study. The materials were evaluated at three stages of screening under natural infection, where Hawassa is selected as hotspot area for sweetpotato viruses based on observations made in the previous years. Genotypes were planted in a single row observation plot in preliminary screening, and randomized complete block design (RCBD) in advanced screening. Symptomatology was used to evaluate the reaction of genotypes in the field and supplemented by three times serological testing (NCM-ELISA) during each experiment using a battery of 10 antibodies against the common viruses known to infect sweet potato. The results of laboratory analysis have ascertained the occurrence of six new viruses not reported to exist in Ethiopia before, viz. C6 virus, Sweetpotato caulimo-like virus (SPCaLV), Sweetpotato chlorotic flecks virus (SPCFV), Sweetpotato mild speckling virus (SPMSV), Cucumber Mosaic Virus (CMV) and Sweetpotato latent virus (SwPLV). All of the newly identified viruses were detected on exotic sweet potatoes obtained from international sources, suggesting the possibility of their introductions along with the planting materials and hence the need of establishing strong quarantine inspection. Among 25 genotypes evaluated in advanced screening, 14 genotypes (13 from exotic sources and one local) were apparently virus free. These materials need be tested at multi-locations for further use in improvement programs. Highly significant difference $(p<0.01)$ was observed for virus disease severity and storage root yield among sweetpotato genotypes indicating the possibility of selection for resistant/tolerant/ clones against sweetpotato virus disease (SPVD). Use of vines from infected fields of sweetpotato resulted in the decline in yield and stand establishment across years. Within virus susceptible genotypes, $47.8 \%-92.6 \%$ yield reduction was witnessed in the third year of the experimental period. Similarly out of planting materials used from infected plots, $75-85 \%$ of the vines showed poor establishment when compared to vines taken from virus free plots. This signifies the importance of periodically renewing planting materials from virus free sources.
\end{abstract}

Key words: Host plant resistance, screening, serological test, virus free planting material, stand establishment.

\section{INTRODUCTION}

Sweetpotato [Ipomeabatatas(L) Lam.] is a crop that is considered to be tolerant to a wide range of edaphic and climatic conditions. It is also tolerant of cold than other tropical root and tuber crops. It can grow at an altitude as high as 2500 m.a.s.I. (Luisa and Robert, 2000). Sweetpotato is a food as well as cash crop worldwide and is the most important subsistence crop in many parts of Africa. In Africa, its production is estimated at 7.5 million metric tons per year, which is about $6 \%$ of the world production (FAO, 2001). In Ethiopia, sweetpotato is commonly grown around densely populated areas in the south, south western and eastern parts of the country. At least 20 million Ethiopians depend on this crop as their source of food (Tofu et al., 2007). About 81,000 ha of arable lands in Ethiopia are covered by sweetpotato (CSA, 2012). In terms of area coverage and production, it ranks second among root and tuber crops next to potato (CSA, 2013). Oromia and the South Nation, Nationalities and Peoples' Regional States (SNNPRS) are the major sweetpotato producers in Ethiopia. These regions alone contribute about $99.4 \%$ of the total production, of which Oromia and SNNPRS, respectively, contribute $52.2 \%$ and $47.2 \%$ (CSA, 2012). Although the crop is increasingly introduced in different parts of Ethiopia and the country has a very suitable climatic and edaphic 
condition for its production, the national average storage root yield of sweetpotato remains low (10 $t$ ha-1). This is quite low as compared to the world average yield of $14.9 \mathrm{t}$ ha-1 (FAO, 2001) and experimental storage root yield ranging between 30 to 73 tha-1 (Hall and Harmon, 1989).

Among the factors contributing to yield reductions in sweet potato, insects and diseases are the major, resulting in yield reduction as high as $98 \%$ (Kapinga et al., 2007). Of the plant pathogens; viruses, fungi and bacteria are responsible for the escalated worldwide economic losses of sweet potato. Among the sweetpotato pests, viruses are the second most important constraint next to sweetpotato weevil (Qaim, 1999). The importance of viral diseases becomes paramount because the crop is highly sensitive to virus infection (Teddy et al., 2011). Previous studies have indicated that the yield loss due to virus infection vary from $50-100 \%$ in different countries. For instance, in Nigeria and Uganda, viruses account for $50 \%$ yield loss; whereas, in East Africa, over $90 \%$ of yield reductions have been associated with viruses (Gibson et al., 1998).

The presence of sweetpotato virus in Ethiopia was first reported in 1986 and identified as Sweetpotato feathery mottle virus (SPFMV) (SPL, 1986). However, the disease had not been a limiting factor in sweetpotato production and productivity until 2004. Subsequent studies have indicated high incidence and occurrence of SPFMV, Sweetpotato virus G (SPVG), Sweetpotato chlorotic stunt virus (SPCSV) and Sweetpotato virus 2 (SPV2) in the country in infecting the crop either singly or in combination (Tamru, 2004; Abraham, 2010; Teddy et al., 2011). In addition, Tewodros et al. (2011) reported the distribution of the disease in Southern region with incidences ranging from $20-100 \%$ and $8.3-30 \%$ in the symptomatic and asymptomatic samples, respectively. In Ethiopia, the root yield reduction due to the synergistic infection of SPFMV and SPCSV was reported to be 37\% (Tesfaye et al., 2013).

Although control of viral diseases remains difficult in subsistence cropping systems (Rukarwaet al., 2010), disease management strategies such as cultural practices, phytosanitary measures, control of vectors and deployment of genetic resistance to prevent or limit the extent of damage have been recommended (Maule et al., 2007; Van den Bosch et al., 2007). Among these, use of disease resistant plants are ideal in terms of effectiveness and sustainability for managing any plant disease in general and SPVD in particular (Maule et al., 2007; Okada et al., 2001; Valverde et al., 2007). The use of sweetpotato resistant varieties to reduce the impact of SPVD under farmer's field were reported earlier (Mianoet et al., 2008). Therefore, the aim of this study was to evaluate the reaction of sweetpotato germplasms of different sources to SPVD and identify promising ones for use in further improvement programs.

\section{MATERIALS AND METHODS}

\subsection{Description of the site}

The study was conducted at Hawassa Agricultural Research Center (HARC) in Ethiopia, from 2011 - 2013 in both belg (short rainy) and meher (main rainy) seasons. The center is located at an altitude of 1,700 meters above sea level with coordinates at $7^{\circ} 4^{\prime} \mathrm{N}$ and $38^{\circ} 31^{\prime}$. The soil is sandy loam and it is suitable for sweetpotato production. The center is known to be hot spot for different viruses where the two important viruses infecting sweet potato, namely SPFMV and SPCSV are equally prevalent (Tewdros. et al, 2011; Abraham, 2010).

\subsection{Planting materials}

Eighty nine germplasm, 37 from International Institute of Tropical Agriculture (IITA) and 52 from Asian Vegetable and Development Center (AVDRC) while the last one from both AVDRC and IITA which have already been introduced and 26 locally available clones (released varieties and local cultivars) of sweetpotato were all obtained from the Department of Horticulture of Haramaya University.

\subsection{Experimental design and management}

\subsubsection{Preliminary screening}

In preliminary screening, twenty vine cuttings of each germplasm and cultivars were planted in single rows on single observation plot in 2011/2012 main cropping season.

Seventy two germplasm and 22 local cultivars which were found free from virus in 2011/2012 main cropping season initial screening experiment were planted in two rows during the 2012 off-season using irrigation. All recommended agronomic practices were applied at appropriate times. 


\subsubsection{Advanced screening}

Twenty five clones (22 germplasms and 3 cultivars) advanced from preliminary screening were further evaluated for two consecutive main cropping seasons in 2012 and 2013. The experiment was laid out in a randomized complete block (RCB) design with three replications. Vines were planted in four rows on a plot size of $3 \mathrm{~m} \times 2.4 \mathrm{~m}$ and were spaced at 60 and $30 \mathrm{~cm}$ between rows and plants, respectively. Variety Guntute, which is known for its susceptibility for viruses (Shiferaw et al, 2014), was planted around the experimental plot to serve as a source of inoculum

\subsection{Virus detection}

Four months after planting, symptomatic leaf samples were collected using plastic bag from the top, middle and basal parts of the stem for virus detection in the laboratory. The collected samples from preliminary screening (115), advanced screening (94) and 25 further advanced screening in (2011, 2012 and 2013) were sent for serological test to Holeta biotechnology laboratory, Ambo crop protection research center and Areka agricultural research center, respectively.

In all tests, one centimeter diameter leaf discs were taken from each sample and sap was extracted. Nitrocellulose membrane enzyme-linked immune sorbent assay (NCM-ELISA) (Aritua et al.1998) was used for the serological test. Each sample was tested against antibodies of 10 viruses which were reported as economically important, namely, SPFMV, SPVG, SPCSV, C-6, SPCaLV, SPCFV, SwPLV, SPMMV SPMSV and CMV.

\subsection{Data collection}

\subsubsection{Assessment of disease incidence and severity scoring}

Visual assessment was started two months after planting and data collected at one month interval until the crop gets matured. Presence and absence of viruses was identified in the field using biological property related to virus interaction with its host. Accordingly severity and incidence of disease was done using the leaf and plant color and size deviation from normal appearance (purple, mosaic, vein clearing) and deformation of leaf size and shape to record virus-positive samples (Gutierrez et al., 2003). Severity was recorded on scale of 1-5 (Njeru et al., 2004) while incidence (I), for each plot, was determined by counting the number of diseased plants out of a total in a plot of $3 \mathrm{~m} \times 1.2 \mathrm{~m}$ area and expressed in percent (\%).

\subsubsection{Yield, storage root size and stand establishment}

Data on root yield, storage root size and stand establishment of 22 genotypes and 3 cultivars was collected for the period of 2012-2013 to see the reaction of those materials when grown under a virus prone environment. Data related to total yield (TY), marketable yield (MY) and unmarketable yield (UMY) was determined by harvesting two central rows in each plot.

Total storage roots (t ha-1) were sorted as unmarketable (blighted, rotten and deformed) and marketable. Storage root diameter was determined from 10 tubers randomly taken from each plot by using a measuring caliper and then mean was computed.

\subsection{Data analysis}

The data on disease incidence and severity, storage root yield (marketable, unmarketable and total yield), root diameter were subjected to analysis of variance (ANOVA). Means were separated following Fisher's protected least significant difference test at 5\% significance level (LSD 5\%). All analyses were done with the Statistical Analysis System (SAS) version 9.1 (SAS Institute Inc., 2003.).

\section{RESULT AND DISCUSSION}

\section{Screening and selection}

In preliminary screening, out of 89 germplasm and 26 cultivars evaluated during the 2011 cropping season, 72 ( $80 \%)$ germplasm and $22(84.6 \%)$ cultivars were found virus free. In this trial only three viruses previously registered in Ethiopia,viz, SPFMV, SPCSV and SPVG (SPL, 1986; Tamru, 2004; Abraham, 2010) were detected. However, the prevalence of viruses was not similar among genotypes. The highest virus incidence recorded was for SPFMV (23\%) 
followed by SPCSV (15\%) on germplasm obtained from AVDRC; while it was $15 \%$ for SPFMV and $8 \%$ for SPCSV on local cultivars. On sweet potato, germplasm obtained from IITA, $8.1 \%$ of the samples were equally infected with SPFMV and SPCSV. On the other hand, low level of SPVG was identified from AVDRC and IITA materials, respectively, with incidence of $3.8 \%$ and $2 \%$.

Of all samples subjected to serological test, $72 \%$ germplasm (IITA and AVDRC) and $87 \%$ local cultivars were found infected by different viruses. In general, 25 genotypes were free from any of the identified viral diseases. In this experiment, in addition to the previously identified ones, (SPFMV, SPCSV \& SPVG) (SPL, 1986; Tamru, 2004), more new viruses such as C-6 virus, Sweetpotato caulimo-like virus (SPCaLV), Sweetpotato chlorotic flecks virus (SPCFV), Sweetpotato mild speckling virus (SPMSV), Cucumber Mosaic Virus (CMV) and Sweetpotato latent virus (SwPLV) were detected. Though the viruses detected in this study were new to Ethiopia, SwPLV, SPCalV, SPCFV and CMV have earlier been identified on sweetpotato in East Africa (Ames, 1997). The two viruses, SwPLV and C-6, have rare occurrence in Africa but frequently identified and are important in Asia and South America (Opiyo1 et al., 2010). Out of six newly identified viruses, SPMSV was detected from both IITA and AVDRC materials; whereas the remaining five viruses detected on only AVDRC germplasm. No local cultivar was found infected with the new viruses. This variation in the reaction of introduced and local sweet potatoes to the newly reported viruses could possibly be explained by the fact that the introductions might already be contaminated at their respective origins, while the local materials are not yet sufficiently exposed to the viruses or may be tolerant to them, though this later speculation may need empirical data to proof.

SPCSV and SPFMV were the most frequently detected viruses being identified from 56.8 and $52.6 \%$ of the samples, respectively. The relative occurrence of remaining viruses was $14.6,4.2,2.1,5.6,3.1,1$, and $1 \%$ in this order, for SPVG CMV, C-6, SPMSV, SPCalV, SP CFV, and SwPLV, (Table1). Mixed infections of two (SPCSV and SPFMV) and three (SPCSV, SPFMV and SPVG) viruses were, respectively, detected from $36 \%$ and $5.3 \%$ of the 94 samples tested (Table 1). Two genotypes were also attacked with mixed infection of SPFMV, SPCSV,SPVG,SPALV and C-6 viruses.

The frequency and occurrence of viruses identified depend on sweetpotato sources. For example, the highest incidences for SPCSV (63\%) and SPFMV (65.8\%) were recorded on sweetpotato germplasm obtained from AVDRC. Ethiopian cultivars showed the highest infection record for SPFMV (63.6\%) followed by SPCSV (50\%), whereas on IITA materials, highest incidence was recorded for SPCSV (52\%) followed by SPFMV (32\%). This result is in agreement with Tewodros et al., (2011) and Abraham. (2010), who reported the prevalence of the two viruses in Ethiopia

In advanced screening, only three viruses earlier reported to occur in Ethiopia, namely SPFMV, SPCSV and SPVG were discovered (Tables, 1 and 2). However, of the 22 germplasms obtained from AVDRC and IITA and three local cultivars, 13 germplasm and one cultivar was virus free under advanced screening (Table 2).

Sweetpotato Virus Disease (SPVD) severity also significantly varied among the sweetpotato genotypes (P $<0.01$ ) in both season (Table 3). Genotypes TIS-8441-6, TIS-82/0602-12, TIS-9068-6, TIS-82/0602-6, TIS-9468-7, TIS--8250-1, TIS-70357-2, CN-2063-6, CN-2066-2, CN-2059-8, CN-1754-5, CN-1754-14 and Becule showed the highest stable reaction against virus diseases in both seasons (Tables 2 and 3 ). Germplasms TIS-82/0602-2, TIS9468-7 and CN-2066-2 showed mild symptom of SPVD with severity score 2, although they were not positive when subjected to serological test (NCM-ELISA) using a battery of 10 antibodies against 10 viruses (Table2). In some circumstances, may be due to low virus concentration in the samples, the inability of NCM-ELISA to detect from symptomatic plants is reported. For instance, Souto et al. (2003) reported that the inability of RT-PCR and NCMELISA test to detect SPFMV in plants known to be infected suggesting that sometimes even symptomatic plants escape detection. 
Table 1. Types of viruses identified on local and exotic sweetpotato genotypes evaluated under natural infection at hotspot area, Hawassa, Ethiopia. 2011-2013 main rainy and off season

\begin{tabular}{|c|c|c|c|c|c|c|c|c|c|c|c|c|c|}
\hline \multirow[b]{2}{*}{ 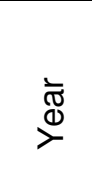 } & \multirow[b]{2}{*}{$\begin{array}{l}\sum_{0}^{0} \\
\substack{0 \\
0} \\
0 \\
0\end{array}$} & \multirow[b]{2}{*}{ 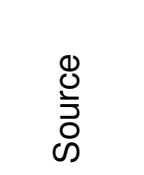 } & \multirow[b]{2}{*}{$\begin{array}{l}\overline{\mathbf{D}} \\
\text { हे } \\
\text { हे }\end{array}$} & \multicolumn{10}{|c|}{ Results of NCM-ELISA testing } \\
\hline & & & & $\begin{array}{l}\text { की } \\
\text { D } \\
\text { क }\end{array}$ & $\underset{\substack{\frac{1}{0} \\
\text { con }}}{\gtrless}$ & $\sum_{\substack{n \\
\infty}}^{\gtrless}$ & 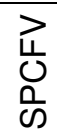 & 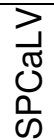 & $\begin{array}{l}\text { U } \\
\text { Ú }\end{array}$ & $\sum_{0}^{\infty}$ & $\begin{array}{l}\text { 尚 } \\
\frac{a}{3} \\
\text { की }\end{array}$ & $\frac{D}{\text { D }}$ & $\sum_{0}$ \\
\hline & & local & 26 & 2 & 4 & - & - & - & - & - & - & - & - \\
\hline \multirow[t]{2}{*}{2011} & & IITA & 37 & 3 & 3 & - & - & - & - & - & - & 2 & - \\
\hline & & AVRDC & 52 & 8 & 12 & - & - & - & - & - & - & 2 & - \\
\hline & Total & & 115 & 13 & 19 & - & - & - & - & - & - & 4 & \\
\hline \multirow[t]{3}{*}{2012} & Variety & local & 22 & 11 & 14 & - & - & - & - & - & - & 2 & 2 \\
\hline & Germplasm & IITA & 34 & 18 & 11 & - & - & - & - & 2 & - & 5 & - \\
\hline & & AVRDC & 38 & 24 & 25 & - & 1 & 3 & 2 & 3 & 1 & 9 & 2 \\
\hline & Total & & 94 & 53 & 50 & - & 1 & 3 & 2 & 5 & 1 & 14 & 4 \\
\hline \multirow[t]{4}{*}{2013} & & local & 3 & 1 & 2 & - & - & - & - & - & - & - & - \\
\hline & & IITA & 11 & 2 & 3 & - & - & - & - & - & - & 1 & - \\
\hline & & AVRDC & 11 & 3 & 6 & - & - & - & - & - & - & 1 & - \\
\hline & Total & & 25 & 6 & 11 & - & - & - & - & - & - & 2 & - \\
\hline
\end{tabular}

${ }^{*} I I T A=$ International Institute of Tropical Agriculture; AVDRC = Asian Vegetable and Development Research Center (AVDRC). SPFMV= Sweetpotato feathery mottle virus; SPVG= Sweetpotato virus G; SPCSV= Sweetpotato chlorotic stunt virus; C-6 virus; SPCaLV = Sweetpotato caulimo-like virus; SPCFV= Sweetpotato chlorotic flecks virus; $\mathrm{SwPLV}=$ Sweetpotato latent virus; SPMMV= Sweetpotato mild mottle virus; SPMSV= Sweetpotato mild speckling virus; $\mathrm{CMV}=$ Cucumber mosaic virus.

Table 2. Reaction of advanced sweetpotato genotypes to major sweetpotato viruses under natural infection at hotspot area, Hawassa, Ethiopia, 2013 cropping season

\begin{tabular}{|c|c|c|c|c|c|c|c|c|c|c|c|}
\hline \multirow[b]{2}{*}{ Genotypes } & \multirow[b]{2}{*}{ Virus } & \multicolumn{4}{|c|}{ Type of virus } & \multirow[b]{2}{*}{ CaLV } & \multirow[b]{2}{*}{ CFV } & \multirow[b]{2}{*}{ LV } & \multirow[b]{2}{*}{ MSV } & \multirow[b]{2}{*}{ MMV } & \multirow[b]{2}{*}{ CMV } \\
\hline & & FMV & SPVG & CSV & C-6 & & & & & & \\
\hline TIS-8441-6 & 1 & - & - & - & - & - & - & - & - & - & - \\
\hline TIS-82/0602-12 & 2 & - & - & - & - & - & - & - & - & - & - \\
\hline TIS-9065-5 & 4 & +++ & ++ & ++ & - & - & - & - & - & - & - \\
\hline TIS-82/0602-2 & 2 & - & - & - & - & - & - & - & - & - & - \\
\hline TIS-80/043-1 & 3 & +++ & - & - & - & - & - & - & - & - & - \\
\hline TIS-9068-6 & 1 & - & - & - & - & - & - & - & - & - & - \\
\hline TIS-82/0602-6 & 1 & - & - & - & - & - & - & - & - & - & - \\
\hline TIS-9065-1 & 3 & ++ & - & +++ & - & - & - & - & - & - & - \\
\hline TIS-9468-7 & 2 & - & - & - & - & - & - & - & - & - & - \\
\hline TIS-8250-1 & 1 & - & - & - & - & - & - & - & - & - & - \\
\hline TIS-70357-2 & 1 & - & - & - & - & - & - & - & - & - & - \\
\hline CN-2065-8 & 3 & ++ & - & - & - & - & - & - & - & - & - \\
\hline CN-2065-10 & 3 & ++ & - & - & - & - & - & - & - & - & - \\
\hline CN-2065-5B & 5 & ++ & - & +++ & - & - & - & - & - & - & - \\
\hline CN-2063-6 & 1 & - & - & - & - & - & - & - & - & - & - \\
\hline CN-2066-2 & 2 & - & - & - & - & - & - & - & - & - & - \\
\hline CN-1752-8 & 4 & ++ & - & ++ & - & - & - & & - & - & - \\
\hline CN-2059-8 & 2 & - & - & - & - & - & - & - & - & - & - \\
\hline CN-2065-18 & 4 & ++ & - & + & - & - & - & - & - & - & - \\
\hline CN-1754-5 & 1 & - & - & - & - & - & - & - & - & - & - \\
\hline CN-1754-14 & 1 & - & - & - & - & - & - & - & - & - & - \\
\hline CN-1753-19 & 5 & ++ & + & - & - & - & - & - & - & - & - \\
\hline Becule-type-1 & 5 & + & - & ++ & - & - & - & - & - & - & - \\
\hline Becule & 1 & - & - & - & - & - & - & - & - & - & - \\
\hline Cuba2 & 3 & ++ & - & - & - & - & - & - & - & - & - \\
\hline
\end{tabular}

* - = negative $;+$ = low color intensity/weak reaction/; ++ = Medium color intensity/medium rection/; +++ = strong color intensity/strong reaction/. FMV = Sweetpotato feathery mottle virus; PVG= Sweetpotato virus G; CSV= Sweetpotato chlorotic stunt virus; C-6 virus; CaLV = Sweetpotato caulimo-like virus; CFV= Sweetpotato chlorotic flecks virus; LV= Sweetpotato latent virus; MSV= Sweetpotato mild speckling virus; MMV= Sweetpotato mild mottle virus; CMV = Cucumber mosaic virus. 


\subsection{Yield, storage root size and stand establishment}

The analysis of variance revealed significant difference $(P<0.01)$ among tested genotypes against SPVD for storage root size, marketable yield, unmarketable yield and total root yield in both seasons. The total yield (t ha $\left.{ }^{-1}\right)$ mean of 2012 and 2013 cropping season obtained from genotypes CN1754-14, TIS-8250-1, CN-1754-5 and TIS-9468-7, in this order, were $61.5,50.0,50$ and 52.1 t ha-1(Table 3 ). The result was in line with the previous works reported by Stephan et al., (2013). The authors explained that variation among varieties in terms of virus resistance is expressed by increased yield and decreased quality loss for resistant verities.

Among the tested genotypes, TIS 9065-1 (4.6 t ha-1), TIS9065-5 (4.1), TIS-80/043-1 (12.6 t ha-1), CN2065-8 (3.9 tha-1) CN-2065-10 (10 t ha-1), CN 2065-5B (2.94 tha-1), CN 1752-8 (3.89t ha-1), CN-2065 18 (10.3 t ha-1), CN-1753-19 (4.8 t ha-1), Becule-type1 (7.05 t ha-1) and Adu (7.6 t ha-1) were susceptible to virus and resulted in low marketable yield compared to resistant genotypes (Table 3). This result further substantiates the need of developing resistant/tolerant sweetpotato cultivars, as virus diseases pose severe yield loss in susceptible cultivars at hotspot areas in many locations. Regina et al. (2007), for example, reported significant yield reduction in sweetpotato due to viruses across the world in general and in Sub-Saharan Africa in particular.

The effect of planting materials used for raising the next season crop from apparently healthy plots for three years for 25 genotypes was determined by measuring the root yield and stand establishment and is depicted in Figure1. The result showed reduction in yield and stand establishment from year to year when virus infected vines used as seed source to grow the next season crop in susceptible genotypes. The reduction ranged from $47.8 \%$ to $92.6 \%$ for yield and from 75 to $85 \%$ for stand establishment (Figure 2). Of the evaluated genotypes, TIS-9065-5 (87.8\%), TIS-80/043-1 (86.9\%), TIS-9065-1 (84.4\%) CN-2065-8 (92.6\%), CN-2065-10 (86.6\%) and CN-2065-5B $(84.0 \%)$ showed overwhelming reduction in yield at the end of the third year (2013) compared to the first base year 2011 (data not shown).

Those vines planted from susceptible genotypes and infected field sources died in seedling establishment of each plot (Figure 2). Stand establishment of seedlings planted from virus free plots was stable except some plots which showed little variation due to their adaptation as well as environmental influence. In general, the stand establishment declined from year to year when using vines from previously virus infected field. In a previous research work, it was reported that the consecutive use of potato tubers from the previous season as a seed source caused the accumulation of virus and could cause degeneration of seeds (Mesfin et al., 2009). After four years continuous cultivation of potato varieties using seeds from previous season, $41-62 \%$ yield reduction was recorded depending on the relative tolerance of each variety (Mesfin et al., 2009).

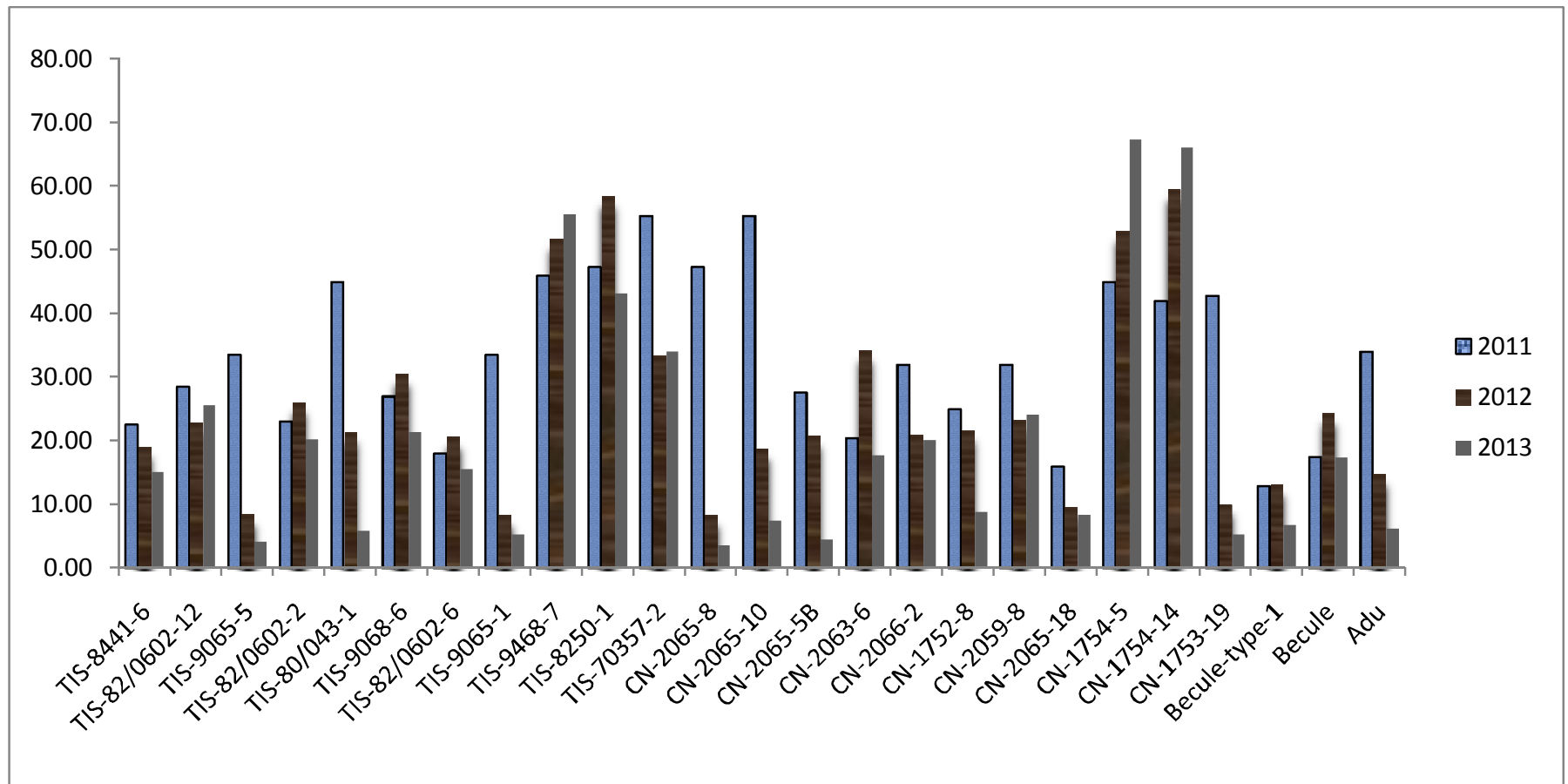

Fig. 1.Trend of sweetpotato yield ( $t$ ha-1) when using apparently virus free vines for three consecutive years 
Table 3. Effects of SPVD severity on yield and yield components of exotic and local sweetpotato cultivars at Hawassa, Ethiopia, during the 2012 \& 2013 cropping seasons

\begin{tabular}{|c|c|c|c|c|c|c|c|c|c|c|c|}
\hline \multirow[t]{2}{*}{ Genotype } & \multicolumn{5}{|c|}{2012} & \multicolumn{5}{|c|}{2013} & \multirow[b]{2}{*}{ mean of } \\
\hline & DSC & DM & MY & UMY & TY & DSC & DM & MY & UMY & TY & \\
\hline TIS-8441-6 & 1.0 & 8.8 & 16.6 & 24.4 & 32.2 & 4.0 & 47.8 & 55.6 & 63.4 & 14.1 & 15.8 \\
\hline TIS-82/0602-12 & 1.3 & 7.7 & 14.1 & 20.5 & 26.9 & 3.3 & 39.7 & 46.1 & 52.5 & 25.6 & 23.5 \\
\hline TIS-9065-5 & 3.3 & 5.0 & 6.7 & 8.4 & 10.1 & 1.8 & 13.5 & 15.2 & 16.9 & 4.2 & 4.1 \\
\hline TIS-82/0602-2 & 2.0 & 6.4 & 24.9 & 1.1 & 26.0 & 2.0 & 6.0 & 19.7 & 0.4 & 20.1 & 22.3 \\
\hline TIS-80/043-1 & 3.0 & 8.7 & 20.1 & 1.2 & 21.3 & 4.7 & 4.1 & 5.1 & 0.8 & 5.9 & 12.6 \\
\hline TIS-9068-6 & 1.3 & 8.0 & 28.1 & 2.0 & 30.1 & 1.7 & 6.2 & 19.1 & 1.2 & 20.3 & 23.6 \\
\hline TIS-82/0602-6 & 1.7 & 6.3 & 17.5 & 3.2 & 20.7 & 1.7 & 4.7 & 14.2 & 1.4 & 15.6 & 15.8 \\
\hline TIS-9065-1 & 4.3 & 4.0 & 5.4 & 3.0 & 8.4 & 4.3 & 3.7 & 3.8 & 1.4 & 5.2 & 4.6 \\
\hline TIS-9468-7 & 1.0 & 15.9 & 50.3 & 2.0 & 52.7 & 1.0 & 9.4 & 54.5 & 1.0 & 55.5 & 52.4 \\
\hline TIS-8250-1 & 1.0 & 21.6 & 57.3 & 1.5 & 58.8 & 1.0 & 9.1 & 41.8 & 1.4 & 43.1 & 49.6 \\
\hline TIS-70357-2 & 1.0 & 8.6 & 31.9 & 3.7 & 35.3 & 1.7 & 6.7 & 33.4 & 0.6 & 34.0 & 32.7 \\
\hline CN-2065-8 & 4.0 & 4.0 & 5.5 & 2.9 & 8.4 & 4.7 & 3.7 & 2.3 & 1.2 & 3.5 & 3.9 \\
\hline CN-2065-10 & 3.3 & 5.4 & 15.3 & 3.5 & 18.8 & 3.7 & 4.0 & 5.5 & 1.9 & 7.4 & 10.4 \\
\hline CN-2065-5B & 3.3 & 6.5 & 17.7 & 2.8 & 20.5 & 4.0 & 3.4 & 2.9 & 1.4 & 4.3 & 10.3 \\
\hline CN-2063-6 & 1.0 & 8.9 & 17.4 & 1.3 & 18.7 & 1.3 & 5.0 & 16.1 & 1.7 & 17.8 & 16.7 \\
\hline CN-2066-2 & 1.0 & 6.4 & 19.2 & 1.0 & 20.9 & 2.3 & 4.7 & 19.1 & 1.0 & 20.1 & 19.2 \\
\hline CN-1752-8 & 3.3 & 7.4 & 17.4 & 4.2 & 21.6 & 4.3 & 4.7 & 5.7 & 3.1 & 8.8 & 11.6 \\
\hline CN-2059-8 & 1.6 & 6.3 & 22.5 & 0.8 & 23.3 & 2.0 & 7.8 & 22.6 & 1.0 & 23.6 & 22.6 \\
\hline CN-2065-18 & 4.7 & 4.0 & 6.5 & 3.3 & 9.8 & 4.0 & 6.0 & 5.0 & 3.3 & 8.4 & 5.7 \\
\hline CN-1754-5 & 1.0 & 11.3 & 51.2 & 1.4 & 52.6 & 1.0 & 10.2 & 66.1 & 1.2 & 67.3 & 58.6 \\
\hline CN-1754-14 & 1.0 & 15.7 & 58.3 & 1.2 & 59.5 & 1.0 & 11.0 & 64.7 & 1.3 & 66.0 & 61.5 \\
\hline CN-1753-19 & 4.3 & 5.7 & 5.8 & 4.2 & 10.1 & 3.3 & 3.4 & 3.9 & 1.4 & 5.3 & 4.8 \\
\hline Becule-type-1 & 3.7 & 4.7 & 10.0 & 3.2 & 13.2 & 3.7 & 5.0 & 4.1 & 2.6 & 6.7 & 7.1 \\
\hline Becule & 1.0 & 6.5 & 22.2 & 2.2 & 24.4 & 1.3 & 4.6 & 16.3 & 1.0 & 17.4 & 19.3 \\
\hline Adu & 3.0 & 6.2 & 11.1 & 3.7 & 14.8 & 3.3 & 4.3 & 4.1 & 2.1 & 6.3 & 7.6 \\
\hline CV (\%) & 28.2 & 25.8 & 27.1 & 41.2 & 24.9 & 24.1 & 25.5 & 35.9 & 58,5 & 33.8 & \\
\hline LSD & 1.2 & 3.4 & 9.9 & 1.6 & 10.1 & 1.1 & 2.4 & 11.17 & 1.4 & 11.3 & \\
\hline
\end{tabular}

DSC = Disease severity score; DM=Diameter; MY=Marketable yield, UMY=Unmarketable yield, TY= Total yield

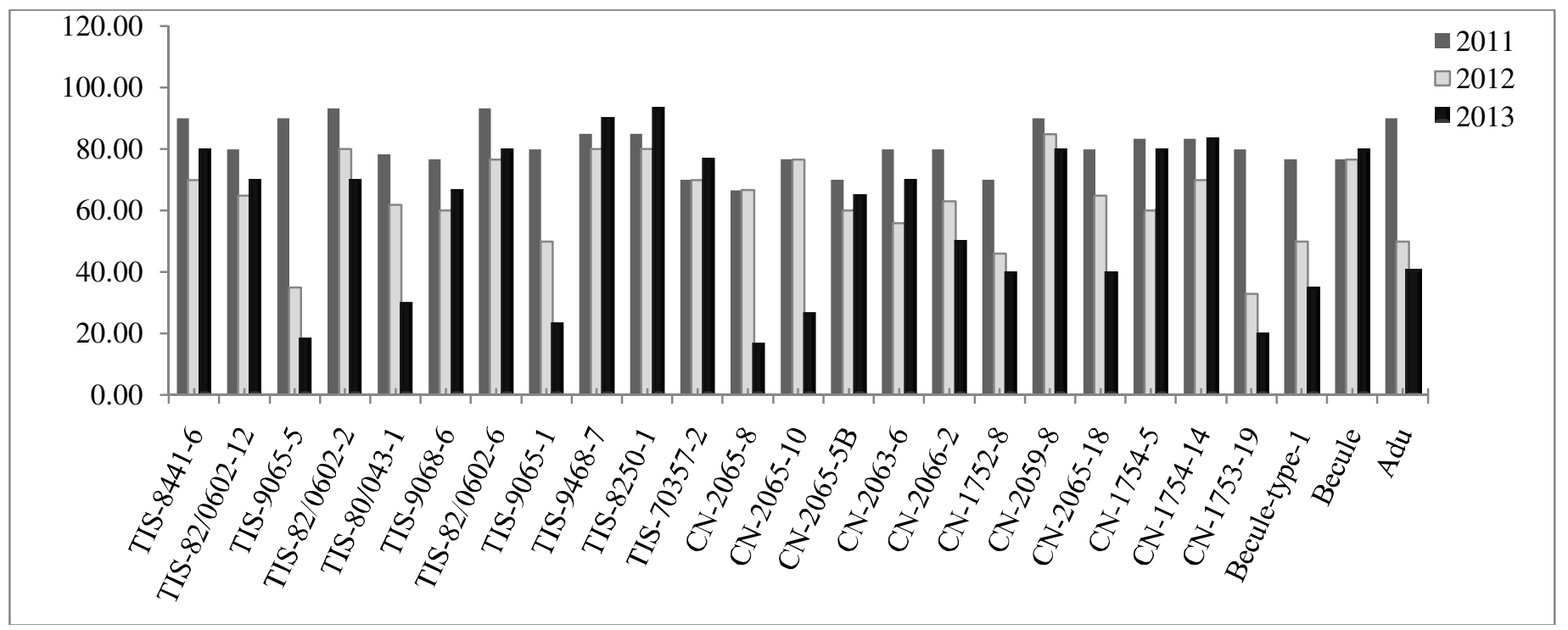

Fig.2. Trend of sweetpotato vine establishment when using apparently virus free vines for three consecutive years 


\subsection{Comparison between parameters for evaluating the effect of virus}

Table 4 showed correlation coefficients for the relationships among sweetpotato virus parameters. Significant positive correlations were found between disease severity and unmarketable yield at Hawassa in 2012 and 2013 with correlation coefficients of $r=0.47$, and 0.29 , respectively. Virus severity was negatively and significantly correlated with marketable and total yield for both seasons. Negative correlations, $r=-0.62$ and -0.68 were revealed between marketable yield and virus severity at Hawassa in 2012 and 2013, respectively. This implies that high severity of virus results in greater reduction of sweetpotato storage root yield and quality yield as marketable refers to non infected roots in addition to root size and shape. In addition, marketable yield was highly correlated with storage root diameter and total yield in 2012 and 2013. The storage diameter was significantly and positively correlated with marketable yield and total yield (Table 4).

Table 4. Relationship between SPVD severity vs total yield and yield components of sweetpotatoat Hawassa during the 2012 and 2013 cropping season

\begin{tabular}{|c|c|c|c|c|c|}
\hline & Vir & $\overline{\mathrm{DM}}$ & $\mathrm{MY}$ & UMY & TY \\
\hline Vir & & $-0.55^{\star \star}$ & $-0.68^{\star \star}$ & $0.29^{\star}$ & $-0.66^{\star \star}$ \\
\hline DM & $-0.59^{* *}$ & & $0.87^{\star \star}$ & $-0.12 n s$ & $0.85^{\star \star}$ \\
\hline MY & $-0.62^{* *}$ & $0.81^{* *}$ & & $-0.24^{\star}$ & $0.99^{\star \star}$ \\
\hline UMY & $0.47^{* \star}$ & $-0.32^{\star *}$ & $-0.39^{* *}$ & & $0-.19^{\star}$ \\
\hline TW & $-0.59^{\star \star}$ & $0.80^{* *}$ & $0.99^{* *}$ & $-0.35^{\star \star}$ & \\
\hline
\end{tabular}

${ }^{*}$ Figures above diagonal are of 2013 whereas below diagonal are of 2012 cropping season $\mathrm{MY}=$ Marketable yield; $\mathrm{UMY}=\mathrm{Unmarketable}$ yield; $\mathrm{TY}=$ Total yield; $\mathrm{DM}=$ Diameter of storage root and Vir $=$ Virus, $\quad{ }^{*}=p<0.05$ and $^{* *}=p<0.01$

\section{CONCLUSION AND RECOMMENDATION}

Sweetpotato is an important food crop in Ethiopia, Viral diseases are considered to be a major limiting factor in sweetpotato production in Ethiopia causing serious losses. In the present study, thirteen introduced germplasms and one Ethiopian cultivar were found virus - tolerant, high yielder and had good stand establishment. These genotypes should be planted across environments to verify further their resistance to sweetpotato viruses.

In this study, six new viruses (SwPLV, SPCalV, SPCFV, CMV, C-6 and SPMSV) were detected. All these new viruses, except SPMSV, were identified from AVDRC sweetpotato germplasm source. SPMSV was detected from both IITA and AVDRC germplasm sources. This result revealed that sweetpotato germplasm introduced from AVRDC were either highly contaminated with virus or they are susceptible to different viruses under Ethiopian conditions. This implies that there is a need to further assess potential sources of virus or alternative hosts and vectors of sweetpotato farms of newly registered viruses from the natural populations of plants of Convolvulacea family.

No new virus was discovered from varieties and cultivars under production in Ethiopia, except those previously identified in Ethiopia as well as East African countries. These are SPFMV, SPCSV and SPVG, which have different levels of infections. This indicated that the previously released varieties and local cultivars found in Ethiopia might not be susceptible to the newly identified viruses in Ethiopia.

It was proved that consecutive use of apparently healthy vine sources from the previous season sweetpotato field resulted in decline of stand establishment and yield due to virus build up during continued vegetative propagation. Therefore, seed sources should be periodically renewed from virus free sources for planting in virus prone areas. 


\section{ACKNOWLEDGMENT}

The authors are grateful for the financial support provided by the Southern Agricultural Research Institute and Hawassa Agricultural Research Center, International Potato Research Center (CIP) based in Ethiopia for its Elisa Kit provision used for virus identification. The Authors also extend their appreciation and acknowledgement to Holeta and Areka biotechnology laboratories and Ambo plant protection research center for their technical and material support during virus detection. Last but not least, the authors are also very thankful to Haramaya University department of Horticulture for providing sweetpotato germplasms.

\section{REFERENCES}

Abraham , A. (2010). Associated viruses threatening sweetpotato improvement and production Ethiopia Africa crop science journal 18: 207-213.

Ames, T., Smit A. R., Braun, J.N., Sullivan. O. and Sokglm L.G. (1997). Major Sweet potato: Major pests, diseases, and nutritional disorders international potato center CIP, Lima, Peru. August, 1997.

Aritua, V. Adipala, E. Carey E.E. and Gibson R.W. (1998).The incidence of sweetpotato virus disease and virus resistance of sweetpotato grown in Uganda. Ann. of Applied Biol. 132: 399-411. Netherlands journal of plant pathology. Volume 90. Issue 4.PP.155-164.

Tofu, A., Teshome, A., Engida,T. and Tesfaye, T. (2007). Summary of Progress on Orange-Fleshed Sweetpotato Research and Development in Ethiopia. Proceedings of the 13th ISTRC Symposium. pp. 728-731.

CSA. 2013 Agricultural sample survey 2012/2013. Report on area and production of major crops. Central Statistical Agency of Ethiopia, Addis Ababa, Ethiopia, (2013), pp. 121.

CSA. 2012. Agricultural sample survey 2011/2012. Report on area and production of major crops. Central Statistical Agency of Ethiopia, Addis Ababa, Ethiopia, (2012), pp. 143.

FAO., FAO Production Year Book, Basic Data Unit, Statistics Division, FAO, Rome, Italy, (2001), Vol. 53, pp. 95.

Gibson, R.W., Alicai T., Carey E.E., Seal S.E., Vetten H.J., (1998). Symptoms, etiology and serological analysis of sweetpotato virus disease in Uganda. Plant Pathology.47, 95-102.

Gutierrez, DL, Fuentes S. and Salazar LF. (2003). Sweetpotato Virus Disease (SPVD): Distribution, Incidence and effect on Sweetpotato yield in Peru. Plants Disease 87:297-302.

Hall, M.R.and Harmon, S.A., (1989). Coastal red sweet potato. Hort.Sci.24:196-177.

Kapinga, R., Ortiz, O., Ndunguru J., Omiat, E. and Tumwegamire, S. (2007). Hand book of Sweetpotato Integrated Crop Management: Research Outputs and Programs for East Africa. International Potato Center (CIP). Uganda

Luisa, H. and Robert, J. H. (2000). A Geographical -Referenced Database of Global Sweetpotato Distribution eds. In: Production Systems and Natural Resource Management Department International Potato Center (CIP). Working Paper No. 4.pp. 1-42.

Maule, A.J. Caranta, C. and Boulton, MT. (2007). Sources of natural resistance to plant virus: status and prospects. Mol ocular plant pathology.223-231

Mesfin, T. Wondirad, M. and Bekele, K. ( 2007). Review of Research on Diseases of Root and Tuber Crops in Ethiopia In. Abraham. T,, eds: Increasing Crop Production through Improved Plant Protection Volume II. Plant Protection Society of Ethiopia (PPSE). Ethiopian Institute of Agricultural Research (EIAR), Addis Ababa, Ethiopia, Volume II. pp. 169-202.

Miano, D., Labonte D, Clark C. (2008). Identification of molecular markers associated with sweetpotato resistance to sweetpotato virus disease in Kenya. Euphytica 160:15-24.

Njeru, R.W., Mburu M.W., Cheramgoi E. Gibson R.W., Obudho E. and Yobera D. (2004). Studies on the physiological effects of viruses on sweetpotato yield in Kenya. Annals of Applied Biology. 145: 71-76

Qaim, M. (1999). The Economic Effects of Genetically Modified Orphan Commodities: Projections for Sweetpotato in Kenya. ISAAA brief No. $13-19$.

Opiyo1 S.A., Ateka E.M., Owuor 1P.O. Manguro1 L.O.A. and Karuri H.W. (2010). Survey of Sweet Virus in Western Kenya and Detection of Cucumber Mosaic Virus. Journal of Plant Pathology. 92 (3), 797-801.

Regina, K., Oscar, O., Joseph, N., Emmanuel, O. and Silver T. (2007). Handbook of Sweetpotato Integrated Crop Management Research Outputs and Programs for East Africa (1995-2006) International Potato Center (CIP), ISBN: 978-92-9060-323-8.

Shiferaw Mekonen, Fikre.H., Fekadu. G., Elias U., (2014). Sweetpotato Diseases Research in Ethiopia. International Journal of Agriculture Innovations and Research Volume 2, Issue 6, pp.933-938. ISSN 2319-1473.

Souto, E.R., Sim J., Valverde R.A. and Clark C.A. (2003). Properties of strains of sweetpotato feathery mottle virus and two newly recognized poty viruses infecting sweetpotato in the United States. Plant Disease 87: 1226-1232 
SPL (Scientific Phytopathological Laboratory). (1986). Progress Report for the Period 1985/86, pp. 252-259. Ambo, Ethiopia.

Stephan, N., Hussein, S., Julia, S. and Kido M. (2013). Review of Sweetpotato breeding for resistance to sweetpotato virus disease and improved yield: Progress and challenges. African Journal of Agricultural. Vol. 8(25), pp. 3202-3215.

Tamru, A. 2004. Characterization of viruses of hot pepper (Capsicum spp.) and sweetpotato (Ipomeabatatas) From Ethiopia. Doctorial dissertation. University of Bonn, pp. 126.

Tesfaye, T., Fikre, H. and Mesele, G. (2013). Prevalence, incidence and distribution of sweet potao virus: Its effect on the yield of sweetpotato in Southern Region of Ethiopia. International Jurnal of Science and research Volume II. Issue 1. PP.591-595.

Tewodros, T., Tielye, F. and Adane A.( 2011). Survey and serological detection of sweetpotato lpomoebatatas (L) Lam.) Viruses in Ethiopia, journal of Applied Biosciences, vol. 41, pp. 2746 -2756 ISSN 1997-5902.

Valverde, R.A., Clark, C.A. and Valkonen JPT (2007).Viruses and virus disease, complexes of sweet potato. Plant Virus. 1:116-126.

Van Den Bosch, F., Jeger, M. and Gilligan, C. (2007). Disease control and its selection for damaging plant virus strains in vegetative propagated staple food crops. Proc. Royal Soc. B: Biol. Sci. 274:11.

Cite this Article: Shiferaw M., Berhanu B., Tesfaye T. and Fekadu G. (2016). Evaluation of exotic and locally adapted sweetpotato cultivars to major viruses in Ethiopia. Greener Journal of Agricultural Sciences, 6(2): 069-078, http://doi.org/10.15580/GJAS.2016.2.011516011. 